\title{
Algorithmic Thinking and New Digital Literacy
}

\author{
Marina S. TSVETKOVA, Vladimir M. KIRYUKHIN \\ Russian Academy of Natural History, Russian Federation, Russia, Moscow, 105037, box 47 \\ e-mail:vkiryukh@gmail.com,ms-tsv@mail.ru
}

\begin{abstract}
The article discusses the concept of algorithmic thinking in the context of the history of the formation of school informatics, in the competencies of new digital literacy and in the system of developmental education. The structure of digital literacy based on algorithmic supports is shown and an example of an educational template of algorithmic tasks for younger students is given.
\end{abstract}

Keywords: digital literacy, school informatics, system of developmental education, algorithmic thinking, primary general education.

\section{Introduction}

The development of algorithmic thinking in children in the 21 st century is an integral part of modern digital literacy, as the ability to learn and develop in a digital environment. In the digital age, it is algorithmic thinking that becomes the intellectual basis for working with digital information to include a person in the modern world of information systems and digital communications. Artificial intelligence, control of machines and digital services in life, study, work, and creativity are of particular importance here.

The world of the digital age is artificially created by people, it is filled with digital devices and programs that make up the services and resources of the digital environment. The challenges of this world are new digital literacy, the competencies of which are based on fundamental knowledge and skills in the subject of informatics. This is algorithmic knowledge and ability to use programs and digital devices, as well as creativity for the implementation of algorithmic ideas in information systems and robotics.

New digital literacy is becoming an integral part of traditional literacy from early childhood for children living in digital environments from birth. And school informatics is a subject that forms digital literacy based on algorithmic thinking. Algorithmic thinking of a person living in a dynamic digital environment affects the duality of the content of informatics - these are the scientific and technological foundations of the 
subject. Science gives rise to all new digital instruments, devices, systems. New digital technologies stimulate the search and development of new algorithms, models and information structures.

\section{Programming is the Second Literacy}

During the formation of the subject of Informatics in the 1970s the Russian scientist Academician A.P. Ershov developed a school informatics course program (Ershov, 1988). He also put forward the thesis "programming is the second literacy" (Ershov, 1981) and this thesis is still relevant now.

Professor S. Papert also predicted an all-round intrusion of the computer into the world of the child, when the computer would become an intellectual tool used by the child with the same immediacy with which he uses a pen and pencil, but with much greater variety. Interpreting Piaget's observations that the child makes most of his intellectual discoveries on his own, provided that the background surrounding him is sufficiently rich, Professor S. Papert showed that the computerization of this background will create a new, unprecedented operating environment that will require new ideas in developmental psychology.

A. Ershov noted: "If the development and spread of typography has led to universal literacy, then the development and spread of computers will lead to universal programming skills. ... It's not about imposing new skills and knowledge on children, but about manifesting and formulating those aspects of thinking and behavior that really already exist, but are formed spontaneously, unconsciously".

It is important that new knowledge and skills are formed in the world of programs: "The world of programs is far from just the filling of computer memory. First of all, this is a huge stock of operational knowledge accumulated by mankind and now only actualized by computers, robots, and automatic devices. An even larger stock of programs is stored in the gene pool of all living things: its decryption and use are largely the subject of biology and its new sections, including genetic engineering” (Ershov, 1981).

A. Ershov also noted the importance of developing these new skills from an early age. "The question of how to teach children the ability to plan their actions and their consequences, what kind of operating environment is needed in this case, is very far from those methodological alternatives that we are discussing, for example, in professional training in programming. On the one hand, we must make this environment natural for the child, on the other hand, it must be rich enough so that he could, as psychologists say, create a theory of a cognizable phenomenon on his own ... The laws of programming, the laws of information processing appear in the form operational rules reflecting the direct experience of humankind ... This is an important statement about the deep and indissoluble connection of operational knowledge and algorithmic thinking with other components of education" (Ershov, 1981).

As a result, the inclusion of algorithmic thinking and programming technology in the fundamentals of the subject of Informatics was recorded. And the subject of com- 
puter science itself over the years of development has become a guarantor of the formation of new digital literacy in schoolchildren on the basis of algorithmic thinking, which is reflected in the Russian school educational standard.

\section{The Role of Algorithmic Thinking in the Developmental Education System in the Digital Age}

In the 20th century, a system of developing education was developed and implemented in Russian schools. This made it possible to place at the center of learning not the process, but the child, his success in development on the basis of educational activities. The basis of activity is the concept of actions, which consist of operations, that is, ways of performing actions. This concept is most fully reflected in the psychological theory of activity, which is associated with the names of Soviet scientists L.S. Vygotsky (Vygotsky, 1934), A.R. Luria (Vygotsky and Luria, 1930), P.P. Blonsky (Blonsky, 1935), S.L. Rubinshtein (Rubinshtein, 1989), P.Y. Galperin (Galperin, 1985) and is described in the book by A.N. Leontyev "Activity. Consciousness. Personality" (Leontiev, 1975).

Algorithmic thinking is based on the system-activity approach, in fact it is operational and includes various approaches based on research by scientists: structures and operations of thinking (Piaget, 1985), computational thinking in cooperation with a computer (Papert, 1988), algorithms and programs in the structure of thinking (Ershov, 1988), action planning and advanced development (Zankov, 1975), research algorithmic approach in operational thinking, thinking operations (Shapiro, 1975), modeling, logical thinking (Elkonin, 2007; Davydov, 1995; Davydov, 1996), interiorization as a process of transforming external, objective actions into internal mental ones, exteriorization - the transition from an internal, mental plan of action to an external one, implemented in the form of techniques and actions with objects (Galperin, 1985).

The essence of the algorithmic approach is that the student is taught not only the concepts of the essential properties of certain objects, but also the rules by which these properties are associated with the actions necessary to solve certain problems (algorithms).

The most important principle of algorithmic thinking is its effectiveness at the level of a mental image of a decision. The key to the disclosure of creative activity in productive activity based on algorithmic thinking is anticipation - the presentation of the result of an action in the mind of a person before it is actually carried out. The computer as a tool for the implementation of algorithmic ideas with feedback has created completely new conditions for the development of algorithmic thinking in children, when the computer becomes a child's assistant for productive activity and creativity, removes the barrier in the formation of an internal image of a solution and the way to achieve it based on the experience of obtaining feedback - a computer sketch, a digital prototype created by him or selected from digital templates. 


\section{Intellectual and Instrumental Pillars of Algorithmic Thinking}

Algorithmic thinking has intellectual and instrumental support, that is, it has dualism: algorithmic knowledge as a formalized method of operational thinking, on the one hand, and algorithmic skills as a tool for implementing algorithmic ideas in practice, on the other hand. These principles of algorithmic thinking are central to the educational process based on algorithmic problems for children.

The intellectual (theoretical) pillars of algorithmic thinking are reflected in the mathematical foundations of informatics, represented by intelligent algorithmic constructs, such as: numbers and coding, digital information, the order of calculations, patterns, combinatorics, probability, sets, logic, information presentation, lists, graphs, relationships, commands and algorithms for the executor, program control real and virtual command executor.

Instrumental (practical) supports ensure the use of ready-made programs, tools for implementing algorithms in a digital environment and are reflected in the technological foundations of informatics in the form of instrumental algorithmic constructs, such as: the computer as a command executor; computer devices, processor and internal memory; program principle of computer control; device management; the computer as a command executor; control commands; program; menu in the program; computer tools for information processing; setting up tools; programming; command executor; automation of program control; net; Internet - an environment for control of information; artificial Intelligence; smart technology.

From these algorithmic constructs base digital literacy competencies are formed.

\section{The Structure of Digital Literacy: The Digital Triangle}

In fact, algorithmic thinking led humanity to the invention of the computer, which is a universal device for implementing algorithms in the form of programs. We can say that algorithmic thinking is the foundation of digital literacy. Intellectual (internal) and instrumental (external) supports of algorithmic thinking form new digital competencies of children only in their unity.

The structure of digital literacy includes three groups of key digital competencies accumulated over decades of development of the digital world: computer literacy, information literacy and communication literacy. Computer literacy has formed a group of digital literacy technical competencies based on a variety of digital devices and programs, automation tools. Information literacy has formed the competence of working and understanding digital information based on a variety of ways of presenting it, including media and virtual reality. Communication literacy was formed on the basis of the globalization of digital communications, including cloud, mobile technologies.

These three groups of digital competencies make up the digital literacy competency triangle. Each group has a typical set of educational actions: intellectual (know, un- 
Table 1

The digital literacy framework

\begin{tabular}{|c|c|c|c|}
\hline $\begin{array}{l}\text { Key } \\
\text { competencies }\end{array}$ & $\begin{array}{l}\text { Intellectual competencies } \\
\text { (know) }\end{array}$ & $\begin{array}{l}\text { Instrumental } \\
\text { competencies (be able to) }\end{array}$ & $\begin{array}{l}\text { Social competences } \\
\text { (act) }\end{array}$ \\
\hline $\begin{array}{l}\text { Information } \\
\text { competencies } \\
\text { (working } \\
\text { with digital } \\
\text { information) }\end{array}$ & $\begin{array}{l}\text { Types of information and algo- } \\
\text { rithmic bases for working with in- } \\
\text { formation. } \\
\text { Methods for presenting digital } \\
\text { information. } \\
\text { The specifics of information pro- } \\
\text { cesses in the digital environment. } \\
\text { The features of computer mo-dels } \\
\text { of objects and processes of various } \\
\text { nature }\end{array}$ & $\begin{array}{l}\text { Work with information } \\
\text { and information struc- } \\
\text { tures. } \\
\text { Process information of } \\
\text { various types on a compu- } \\
\text { ter. } \\
\text { Use smart tools to apply } \\
\text { and create algorithms, mo- } \\
\text { dels, and programming. }\end{array}$ & $\begin{array}{l}\text { Work with information to } \\
\text { control various devices. } \\
\text { Self-adapt to new ways of } \\
\text { working with information, } \\
\text { such as: multimedia, virtual } \\
\text { reality, simulators, robotic de- } \\
\text { vices and robotic programs, } \\
\text { cyberworlds in everyday life } \\
\text { and public space }\end{array}$ \\
\hline $\begin{array}{l}\text { Technical } \\
\text { digital } \\
\text { competencies }\end{array}$ & $\begin{array}{l}\text { The composition of the com-puter } \\
\text { and the purpose of digital devices. } \\
\text { The programmatic principle of the } \\
\text { computer. } \\
\text { Variety of digital devices and } \\
\text { programs. }\end{array}$ & $\begin{array}{l}\text { Use various interfaces to } \\
\text { control digital devices. } \\
\text { Work on a computer in } \\
\text { different software environ- } \\
\text { ments. }\end{array}$ & $\begin{array}{l}\text { Apply tools for working } \\
\text { with new digital devices. } \\
\text { Get involved in working } \\
\text { with digital information in } \\
\text { different and new software } \\
\text { environments independently. }\end{array}$ \\
\hline $\begin{array}{l}\text { Digital } \\
\text { communica- } \\
\text { tions }\end{array}$ & $\begin{array}{l}\text { Composition and principles of } \\
\text { operation of computer networks and } \\
\text { the Internet. } \\
\text { The structure of the presentation } \\
\text { and transmission of information in } \\
\text { the network. Information security } \\
\text { rules and responsibility. }\end{array}$ & $\begin{array}{l}\text { Work in services, resour- } \\
\text { ces of the digital environ- } \\
\text { ment. } \\
\text { Use the methods of pre- } \\
\text { paring messages, search- } \\
\text { ing, transferring informa- } \\
\text { tion. } \\
\text { Safely organize your per- } \\
\text { sonal information space. }\end{array}$ & $\begin{array}{l}\text { Apply personal and collec- } \\
\text { tive, private and public digital } \\
\text { communications services in } \\
\text { life, creativity, study, work. } \\
\text { To be included in new re- } \\
\text { sources of networked smart } \\
\text { systems. } \\
\text { Adapt to AI devices and } \\
\text { services. }\end{array}$ \\
\hline
\end{tabular}

derstand, explain information processes and digital objects of information activity), instrumental (be able to, own digital devices, resources and tools for working with them) and social (act in the digital world, independently apply in digital environment, transfer digital skills to new situations in the context of the emergence of innovative digital resources). The digital literacy framework is presented in the Table 1 .

\section{Educational Pillars for the Development of Algorithmic Thinking}

Algorithmic thinking is always embedded in the context of digital literacy, constituting its intellectual and instrumental basis. The main value of algorithmic thinking in the digital literacy system is a change in the technical approach (training on specific information activity tools) to an algorithmic approach, that is, the formation of knowledge and skills to apply generalized algorithmic constructs in information activities in a digital environment, transferring them to new digital devices, tools and software environments independently. 
The question arises, how to teach operational thinking based on an algorithmic approach? In school education, digital literacy is formed in the informatics course, where algorithmic thinking is the main thing, but transfers the acquired knowledge and skills to all school subjects. The difference in informatics is that it is a subject that, by shaping digital literacy, complements all the traditional types of children's literacy.

It can also be said that the intellectual pillars of algorithmic literacy are formed in mathematics and philological subjects such as mathematical and reading literacy based on algorithmic thinking in primary school and further in basic school in natural science and humanitarian subjects. This is done within the framework of research and modeling based on algorithmic thinking, including analysis and synthesis, concretization and generalization, logic and relationships, cause-and-effect relationships, systematization, etc.

The instrumental supports of algorithmic thinking are manifested in digital literacy and are formed in the technological and practical aspects of activities in natural science and humanitarian subjects, in information technology. They are also embedded in the objective activity of art and technology according to design algorithms, mastering the tools of creativity, and in health-saving subjects (physical culture, the basics of life safety), built on instructions and algorithms for behavior and decisionmaking.

\section{Typical Educational Tasks Based on Algorithmic Constructs}

The main problem of the formation of digital literacy of children on the basis of algorithmic thinking in the context of information activities is to offer a set of educational tasks that are built into all types of school subjects. These can be interdisciplinary algorithmic problems with obligatory computer support. Each task has an algorithmic step (intellectual construct) and a digital step (instrumental computer construct), which determine the educational activities of children to master digital literacy. From these steps, initial digital literacy is built for younger schoolchildren, which is important for their further development - this is a "digital bridge" to the new literacy of children.

Below are five content blocks of such typical tasks. They are intended for all age groups of schoolchildren, but they are implemented by different types of tasks, taking into account the age of the children. The result of mastering the blocks of educational tasks is the independent use of not only algorithmic approaches for information processing, but also tools for working on a computer, taking into account the age characteristics of children.

The highlighted blocks correspond to the groups of digital literacy competencies described above: information digital literacy - working with digital information, technical computer digital literacy and communication digital literacy. On the basis of algorithmic thinking and the practice of using digital devices and computer programs, intellectual (know, understand) and instrumental (be able, get digital experience) constructs of digital literacy are distinguished in each block. 


\subsection{Block of Tasks "Models of Information Structures and Their Parameters"}

Intelligent constructs (algorithmic step): alphabet, transcription, musical notation, list, catalog, table, diagram (block diagram), graph, tree, network, diagram, graph, drawing, geometric shapes, text layout, formula (arithmetic expression), map, plan, pictogram, barcode, digital code, index, address, file, folder, directory.

Instrumental constructs (digital step): digital information and binary code; file system and screen interface constructs, digital text and its constructs (page, format, paragraph, fragment, font, hyperlink, table, illustration), configuring construct parameters; computer graphics constructs and their customization (raster, vector, graphic objects, object transformation, palette, color); multimedia constructs (video, sound on a computer, interactive environments); spreadsheet constructs, databases; constructs of e-mail, website, search engine.

\subsection{Block of Tasks "Digital Control Models: Algorithms and Programs"}

Intelligent constructs (algorithmic step): action plan, step, command; algorithmic structure (linear, branching, logic, cycle), algorithmic decision models; command writing rules, programming language syntax, choice from a set of commands, result analysis, command ordering plan logic.

Instrumental constructs (digital step): control of virtual and real executor of commands, system of executor's commands; computer - command executor, operating system, program interface tools, types of interfaces and interface devices (keyboard, remote control, voice control, touch panel, on-screen manipulator); application programs for processing data of various types, an algorithm of actions with tools of the software environment, menus, setting the parameters of tools in the program, computer template, layout, prototype, embedded objects.

\subsection{Block of Tasks "Models of Information Processes and Information Activities"}

Intelligent constructs (algorithmic step): actions - collecting and observing information, organizing information, fixing information (forms of presenting information of various types), processing information (methods of processing information of various types), storing information (directory and its structure, file, folder on devices storage, computer temporary memory and binary codes, cloud storage structure); form of information transfer (information structure of the digital communication system, data transfer), information search (search logic), information analysis (screen presentation of information, hypertext, augmented reality, information protection, information threats - an algorithm of actions). 
Instrumental constructs (digital step): digital devices, digital device software, program menu interface, program tool setting interface, text input interface, digital writing, computer interface, browser command interface, search interface; means of information protection, rules of social behavior in the digital environment.

\subsection{Block of Tasks "Information Systems: Algorithmic Models in the Digital Environment"}

Intelligent constructs (algorithmic step): the world of automatic devices of software systems; algorithms of human functioning in the world of information systems, information systems for people with special needs; shadow internet and positive internet, MOOCs, e-learning platforms, cyber-physical systems, information systems and professions.

Instrumental constructs (digital step): digital steps - tests of digital competencies in a hybrid digital environment of people, cyber machines and robot programs and algorithms for their interaction; satellite navigation systems, examples of cyber-physical systems in the service of humans, unmanned devices, automated control systems; virtual reality and human, examples of cyberworlds, cyberculture and cyberart; systems with artificial intelligence, examples of smart systems in various fields of activity, in public space; digital life.

\section{5. Block of Tasks "Models of Actions in the Environment of Digital Communications"}

Intelligent constructs (algorithmic step): algorithmic bases of interaction in computer networks; the procedure for safe actions in the digital environment, publicly available personal and collective options for digital interaction: video systems in society, network subcultures, the blogosphere, educational platforms, gaming platforms, e-commerce, social digital services; dealing with threats and countering dependence on the digital environment and the blogosphere.

Instrumental constructs (digital step): digital communication tools, digital governance - artificial intelligence, big data and society, social information systems, media content; social threats of the digital world - Internet content, services, big data in digital communications and algorithms for managing society through virtual space, bot programs, invasion of private and public space; psychological threats of the digital world in cyberspace - laykomaniya, Internet addiction, computer gambling addiction, digital crime; physical threats of the digital world and the variety of digital devices in everyday life - safety equipment, sanitary standards, physical inactivity and health preservation in the digital environment. 


\section{An Example of an Algorithmic Task Template for Younger Schoolchildren}

The early development of algorithmic thinking is based on computer-based algorithmic problems. There are many examples of such tasks, but the activity aspect of development is most fully reflected in problematic tasks that stimulate the simplest approaches to modeling based on algorithms. Let us give an example of a template of algorithmic problems for younger schoolchildren from the set of microprojects "The Informatics Land" (Fig. 1), published in the Informatics problem book for younger schoolchildren (Tsvetkova, 2018; Tsvetkova, 2018).

The micro-project in each task is designed for one algorithmic step, the implementation of which is an independent achievement for the child, a discovery, like a eureka. This algorithmic step is the fulcrum for the development of new aspects of algorithmic actions and creativity based on these actions.

All tasks are built in the form of an algorithmic template "Robot Question" for seven thematic modules (Fig. 1): the Electronics River (computer structure), the Pier of Sets, the Pier of Logic, the Pier of Algorithms, the Pier of Patterns, the Pier of the coordinate Grid, and the Pier of Graphics. Computer support is provided by the open educational media resource "World of Informatics" in 4 parts (Cyril and Methodius, 2015), which children "attend" at the end of each lesson for 10-15 minutes according to the project

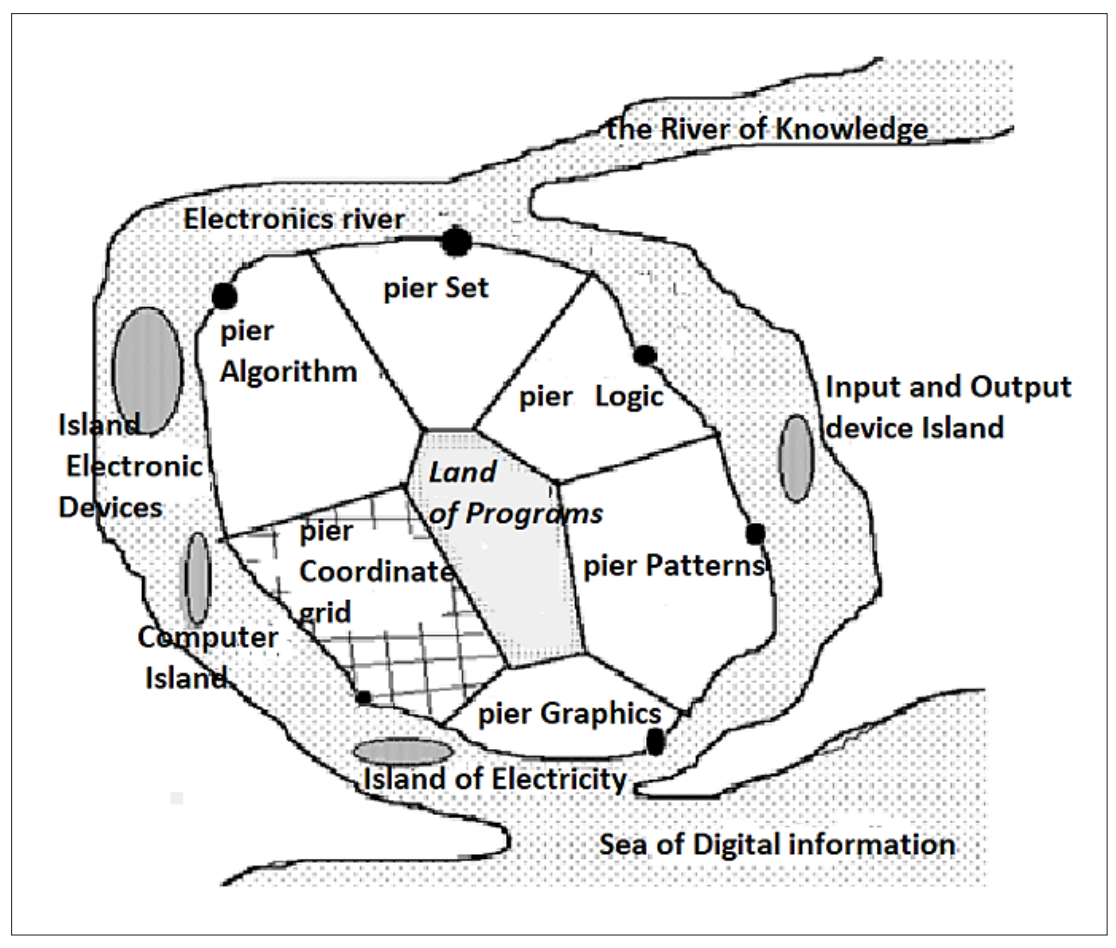

Fig. 1. Scheme of "Informatics Land". 
scenario, and perform the tasks of programmed control of the robot Transporter. Additionally, a set of 100 algorithmic problems is presented in the book "Computer Science Virtual Laboratories" (Tsvetkova and Kuris, 2015): the concept of this algorithmic tasks is described in the article (Tsvetkova and Kiryukhin, 2016).

The microproject as an algorithmic task is intended to familiarize with the design activities of younger schoolchildren on the basis of algorithms. The goal is to teach a child to go through two stages in algorithmic activity: intellectual (to create a model for solving a problem and an algorithmic image) and instrumental (to draw up, show this solution by means of digital literacy on a computer as a computer sketch of an idea). As a result, children can complete a project in a subject environment using a computer or perform work in creative material based on a computer sketch with drawing tools, paper, textile design, assembly and control of a robot, a screen performer control program, mathematical actions according to an algorithm, or lexical actions (digital input, design of creative text, script), design of a physical training warm-up, observations, fixation and design in the form of illustrations, tables, diagrams, diagrams.

Thus, a computer sketch based on an algorithm becomes an educational support a digital step from the idea of solving a problem to its embodiment in creativity, discovery.

The hero of all tasks is the robot Question, which sets the format of the computer sketch based on the algorithm diagram. The name of the robot, the virtual assistant to the schoolboy, was not chosen by chance. It is known that in case of difficulties when performing work on a computer, you can always use the "Reference" or "Help" command. Often this command is indicated by a question mark on the computer screen. Therefore, the hero of the problem book is called so - the robot Question.

In each topic of the practical work, he will be joined by new heroes in the form of robot- assistants. These are the Verbalist (will help us perform tasks for processing symbols: letters, numbers, signs), the Designer and the Builder (will help to construct various objects), the Artist and the Printer (will help us use drawing and graphics tools when doing the work), the Calculator (will help to solve problems, numerical puzzles and magic tricks), the Thinker and the Black Box (will help solve logical problems and find a plan-algorithm for solving problems), Traveler (will help to control the behavior of the executor in steps and directions), Postman (will help to find the necessary addresses), Scrambler (will help to complete tasks on message encoding and decoding).

To help in the solution, a template is used - a diagram of the algorithm for solving the problem. This scheme is the same for all tasks and is a drawing of a robot (Fig. 2). So, the "body" of the robot has three blocks for each task: input data, processing unit (algorithm) and output data (result). It is necessary to write down the task in the album, filling in the corresponding scheme - picture.

A micro-project scenario in any subject problem includes the ability to distinguish an algorithmic structure: input information (given), output information (solution), algorithm (model) of the solution. Hence, the levels of complexity (differentiation) of the microproject arise:

1) The input, the algorithm and the output are known (conceptual, demo).

2) The input and the model are known, build the exit (reproductive). 
3) The algorithm and the output are known, construct the input (reverse reproductive).

4) The input and output are known, build an algorithm (productive).

5) the algorithm is known, pick up the input and output (reverse productive).

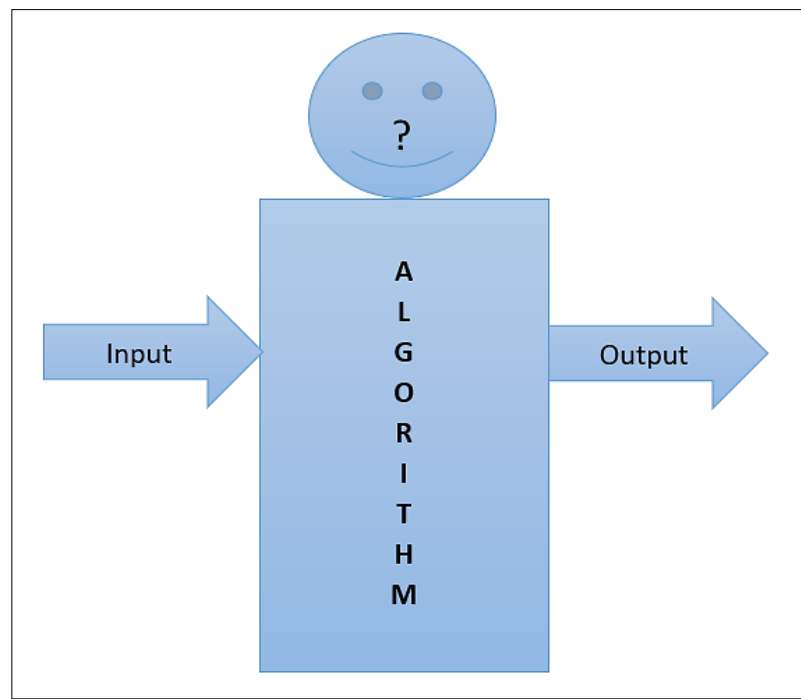

Fig.2. Problem diagram "Robot Question".

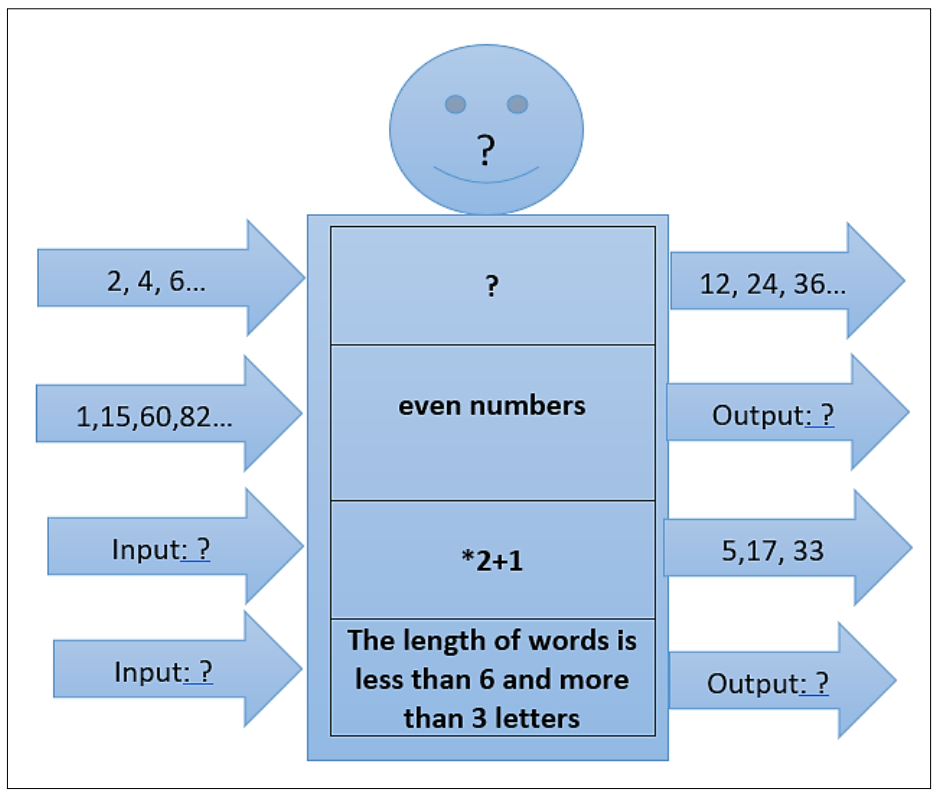

Fig. 3. Example task "Robot-Calculator". 
Fig. 3 shows the robot Calculator task template that demonstrates the possible thresholds for the task's complexity.

Each section of the problem book offers a set of tasks on the topic of the section. The teacher and children can develop problem sets themselves by transferring algorithm templates for their ideas.

\section{Conclusion}

The development of algorithmic thinking in the system of mastering the basics of digital literacy by children from an early age is a new literacy in the digital transformation of the world. This knowledge and digital skills should be made universally for children, as should basic traditional literacy accessible to all children. It is a digital bridge to the ever-changing information world. It eliminates the digital divide for children and helps them make full use of the digital environment for learning and development, and find their professional mark in the near digital future.

In our time, the predictions of Academician A. Ershov (Ershov, 1981) remain relevant, that the task of the school is "to update the information model of the world in the form of programs". "The constant complication of the environment requires and at the same time makes it possible to significantly increase the intellectual power of mankind. A significant place in this progressive development of human intelligence should be occupied by the laws of information processing, ways of transition from knowledge to action, the ability to build programs, reason about them and foresee the results of their implementation".

The concept of new digital literacy based on algorithmic thinking, described in this article, is implemented in Russian primary schools in the form of an author's learning program, textbooks and manuals on Informatics (Tsvetkova et al., 2019), as well as learning programs and textbooks on information security (Tsvetkova and Yakushina, 2020) for primary school.

\section{Reference}

Ershov, A. (1981). Programming, the second literacy. In: Computer and Education: Proc. IFIP TC-3 3rd World Conf. on Computer Education - WCCE 81. Lousanne, Amsterdam, 1981. Part 1. P.1-17 (in Russian: Пpoграммирование вторая грамотность. Выступление на 3-й Всемирной конференции ИФИП и ЮНЕСКО по применению ЭВМ в обучении, 27-31 июля 1981 г. в Лозанне (Швейцария): http://ershov.iis.nsk.su/ru/second_literacy/article

Ershov, A. (1988). School Informatics in the USSR. In: Children in the Information Age: Opportunities for Creativity, Innovation and New Activities: Second International Conference - Sofia, Bulgaia, 19-23 May, 1987. Pergamon Press, p. 37-57. https://books.google.ru/books?id=ISaoBQAAQBAJ\&pg=PA54\&lpg=P A54\&dq=WCCE+81 . +Lousanne, +Amsterdam, +1981 . +Part+1 .+P . +1-17\&source=bl\&ot s=iVE4vyB QMb\&sig=ACfU3U1ToDGjStz0QTW95TeIONNqrOkcIA\&hl=ru\&sa=X\&ved=2ahUKEw j Sj s 2 JpLrwAhXIt YsKHZQPB80Q6AEwCXoECAQQAw\#v=onepage\&q=WCCE $\% 2081 . \% 20$ Lousanne $\% 2 \mathrm{C} \% 20$ Amsterdam $\% 2 \mathrm{C} \% 20$ $1981 . \% 20$ Part $\% 201 . \% 20$ P. $\% 201-17 \& f=$ false 
Papert, S. (1988). A critique of technocentrism in thinking about the school of the future. In: Children in the Information Age: Opportunities for Creativity, Innovation and New Activities: Second International Conference-Sofia, Bulgaia, 19-23 May, 1987. Pergamon Press, p. 3-19.

https://books.google.ru/books?id=ISaoBQAAQBAJ\&pg=PA54\&lpg=PA54\&dq=WCCE+81 .+Lousanne , +Amsterdam , +1981 .+Part+1 .+P.+1-17\&source=bl\&ots=iVE4vyBQMb\&sig=ACfU3U1ToDGjStz0QTW95 TeIONNqrOkcIA\&hl=ru\&sa=X\&ved=2ahUKEw j Sjs2JpLrwAhXltYsKHZQPB80Q6AEwCXoECAQQAw\#v=onepa ge\&q=WCCE $\% 2081 . \% 20$ Lousanne $\% 2 C \% 20$ Amsterdam $\% 2 C \% 201981 . \% 20$ Part $\% 201 . \% 20 \mathrm{P} . \% 201-17 \& f=$ false

Piaget, J. (1985). Equilibration of cognitive structures. University of Chicago Press. https: //piaget .org/

Vygotsky, L. (1934). Thinking and Speaking (in Russian: Мышление и речь. М.; Л.: Соцэкгиз, 1934. Р.323)

Vygotsky, L., Luria, A. (1930). Tool and Symbol in Child Development. https://www.marxists .org/archive/vygotsky/works/1934/tool-symbol.htm

Blonsky, P. (1935). Memory and Thinking (in Russian: Память и мышление. Москва, 1935, с. 215): http://elib.gnpbu.ru/text/blonsky_pamyat-myshlenie_1935/go,0;fs,1/

Rubinshtein, S. (1989). Fundamentals of General Psychology (in Russian: Основы общей психологии. В 2-х томах, Т. 2, Часть 4. М, Педагогика, 1989):

http://elib.gnpbu.ru/text/rubinshteyn_osnovy-obschey-psihologii_t2_1989/go,5;fs,1/

Zankov, L. (1975). Learning and Development (Experimental Pedagogical Research) (in Russian: Обучение и развитие (Экспериментально-педагогическое исследование). М.: Педагогика, 1975. 440 c.)

Elkonin, D. (2007). Child Psychology: Tutorial. Publishing Center “Academy”, Moscow (in Russian: Детская психология: учебное пособие. М.: Издательский центр «Академия», 2007. 384 c): http://psychlib.ru/mgppu/Edp-2007/Edp-001.htm\#\$p1

Davydov, V. (1996). Developmental Learning Theory. Moscow, INTOR (in Russian: Теория развивающего обучения. М.: ИНТОР, 1996): http: //www.psy.msu.ru/people/davydov.html

Davydov, V. (1995). On the Concept of Developing Education: Collection of Articles. "Peleng", Tomsk (in Russian: О понятии развивающего обучения: сб. статей. «Пеленг», - Томск, 1995):

http://elib.gnpbu.ru/text/davydov_o-ponyatii-razvivayuschego-obucheniya_1995/ go, $0 ; f \mathrm{~s}, 0 /$

Galperin, Р. (1985). Teaching Methods and Mental Development of the Child. (in Russian: Методы обучения и умственное развитие ребенка. - M., 1985): http://www.psy.msu.ru/people/galperin.html

Leontiev, A. (1975). Activity. Consciousness. Personality. (in Russian: Деятельность. Сознание. Личность. M, 1975): http://www.psy.msu.ru/people/leontiev/dsl/index.html

Shapiro, S. (1975). From algorithm to judgment. (in Russian: От алгоритма к суждению. М, Советское радио, 1975, с. 288)

Tsvetkova, М. (2018). Informatics. Problem book for grade 3. (in Russian: Информатика. Задачник для 3 класса. Издательство “БИНОМ”. М. 2018): https://lbz.ru/books/750/7762/

Tsvetkova, M.S. (2018). Informatics. Problem book for grade 4. (in Russian: Информатика. Задачник для 4 класса. Издательство “БИНОМ”. М. 2018): https://lbz.ru/books/750/9159/

Cyril and Methodius (2015). World of Informatics. Open electronic resource (OER), Cyril and Methodius Company. (in Russian: Мир Информатики. Открытый электронный ресурс в 4-х ч., “Кирилл и Мефодий” - M. 2015): https://1bz.ru/metodist/authors/informatika/5/ep-4-umk3-4fgos.php

Tsvetkova, M., Kuris, G. (2015). Virtual laboratories for Informatics in primary school: a methodological manual and Open electronic resource (OER). (in Russian: Виртуальные лаборатории по информатике в начальной школе: методическое пособие и открытй электронный ресурс. Издательство "БИНОМ". M. 2015): https://lbz.ru/books/1112/5211/

Tsvetkova, M., Kiryukhin, V. (2016). Concept of Algorithmic Problems for Younger Students Olympiads in Informatics. Olympiads in Informatics, 10 (special issue), 67-78.

Tsvetkova, M., et al., (2019). Educational-methodical set of the team of authors "Informatics" 3-4 classes. (In Russian: УМК авторского коллектива «Информатика» 3-4 классы. Издательство “БИНОМ”. М.): https://lbz.ru/books/750/

Tsvetkova, M., Yakushina, E. (2020). Information Security. Safe Internet Rules. Grades 2-4: tutorial. (In Russian: Информационная безопасность. Правила безопасного Интернета. 2-4 классы: учебное пособие. Издательство “БИНОМ”. М.): https ://1bz.ru/books/1097/11206/ 


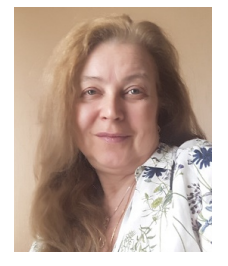

M.S. Tsvetkova, professor of the Russian Academy of Natural Sciences, $\mathrm{PhD}$ in pedagogic science, prize-winner of competition "The Teacher of Year of Moscow" (1998). from 2002 to 2018 she is a member of the Central methodical commission of the Russian Olympiad in informatics and the pedagogic coach of the Russian team on the IOI. She is the author of many papers and books in Russia on the informatization of education and methods of development of talented students. She is the author of official textbooks and copybooks in Russia for primary school in Informatics. She is author and director of the International school in Informatic ISIJ (since 2017). She is the Russian team leader (2013-2017). She was awarded the President of Russia Gratitude for the success organizing the training of IOI medalists (2016). She is now the Expert of Committee on Education and Science State Duma of the Russian Federation (since 2017), and she has the Committee on Education and Science State Duma Gratitude (2021).

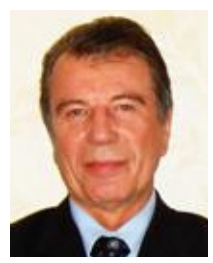

V.M. Kiryukhin is professor of the Russian Academy of Natural Sciences. He is the author of many papers and books in Russia on development of Olympiad movements in informatics and preparations for the Olympiads in informatics. He is the exclusive representative who took part at all IOI from 1989 to 2017 as a member of the IOI International Committee (1989-1992, 1999-2002, 2013-2017) and as the Russian team leader (1989, 1993-1998, 2003-2012). He received the IOI Distinguished Service Award at IOI 2003, the IOI Distinguished Service Award at IOI 2008 as one of the founders of the IOI making his long term distinguished service to the IOI from 1989 to 2008 and the medal "20 Years since the First International Olympiad in Informatics" at the IOI 2009. He was the chairman of the IOI 2016 in Russia, and has the award medal of the President of Russia (2016) for organizing the Olympiad in Informatics in Russia and training IOI medalists since 1989. He is now the President of the international organizing Committee ISIJ. 